\title{
Financial and Support Policies Enabling Absorptive Capacity and Technology Acquisition in Iran's Civil Aircraft Industry
}

\author{
Mohammad Hossein Sabour ${ }^{1}$, Mahdi Mohammadi ${ }^{2} \&$ Erfan Khosravian $^{3}$ \\ ${ }^{1}$ Assistant Professor, Department of Aerospace, Faculty of New Sciences \& Technologies, University of Tehran, \\ Iran \\ ${ }^{2}$ Assistant Professor, Faculty of Management, University of Tehran, Iran \\ ${ }^{3} \mathrm{PhD}$ student, Department of Aerospace, Faculty of New Sciences \&Technologies, University of Tehran, Iran \\ Correspondence: Mohammad Hossein Sabour, Assistant Professor, Department of Aerospace, Faculty of New \\ Sciences \& Technologies, University of Tehran, POB: 14395-156, North kargar St, Tehran, Iran. E-mail: \\ sabourmh@ut.ac.ir/memohammadi@ut.ac.ir/E.Khosravian@ut.ac.ir
}

Received: March 2, 2016

Accepted: March 15, 2016

Online Published: April 10, 2016

doi:10.5539/mas.v10n6p87

URL: http://dx.doi.org/10.5539/mas.v10n6p87

\begin{abstract}
The aircraft industry has a significant role in country's economic and sufficient investment in that, guarantees the long-term economic growth. This industry has facilitated the connection of local industry to global industry and will affect the country productive and economic performance. Due to the importance of aircraft industry, conducting various studies to design its development pattern seems essential to provide appropriate as well as efficient financial and support policies for absorptive capacity development of this industry. In the present study, first, those industrial patterns that are implemented in different countries have been examined in general. In addition, financial and support policies of different countries in aircraft industry are taken into consideration and the course of these supports have been drawn. Then, regarding the experiences of other countries as well as the economic, industrial and political conditions of Iran through field studies and interview with experts, the appropriate policies for constructive interaction between Iran's civil aircraft industry and government are introduced and ranked by analytic hierarchy process (AHP) method.
\end{abstract}

Keywords: Civil aircraft industry, Government support patterns, AHP method

\section{Introduction}

In the definitions of industrial development strategy and the necessity to develop it, the government centrality is adopted as an institute responsible for the mission of regulating economic relations as well as creating a stable environment. In fact, the development of industrial strategy by governments supports this important message that basically, the government considers a special mission along the industrial development for itself. Therefore, now in the world economic and political thought levels, what is the response to this question that "what is government role in absorptive capacity development in civil aircraft industry?" How much the government can intervene in affairs and which fields are forbidden? These issues put the government at the center of debates. Nowadays, it is apparent that previously, in application-oriented way of thinking, important issues such as the formation and function of socioeconomic institutions have been neglected. On the other hand, the speed of changes in the direction of globalization has made governments to take attention to the important variables and factors of global economy and the limitations arising from it more than ever regarding adjusting and intervening affairs such as taxes, regulations related to investment or trade policies. At the same time, advances in technology provided market and forced with new opportunities. Therefore, this has changed the role of governments from provider to facilitator and regulator of affairs. Innovation in organization and changes in technology has provided the possibility in order to let private producers to enter activities related to infrastructure affairs; therefore, governments have made distinction between infrastructure financing and construction and delivery of these services.

Here, the capabilities of governments mean their power in undertaking and strengthening decision making environment as well as collective action in an effective way. This key concept which is rooted in the principles of political economy points to a public strategy and can play its role under that government as an effective and 
efficient partner in industrial development.

\section{Methodology}

Industrial development pattern is the subject of various studies. The purpose of the present study is leading policy makers toward adopting right, effective and efficient policies. Nowadays, the pace of development has been increased and any mistake in policy making could have irreparable consequences. Of course, in examining the history of industrial development, it is important to note that the mere emulation of the successful bids, without taking into account country-specific conditions as well as current situation of world, cannot be as appropriate strategy. Because, without correct understanding of countries' development procedure as well as necessary thinking in observing the effects of implemented policies, applying the existing frameworks can lead to costly and inefficient results. Therefore, the situation of this industry in Iran is examined. Then, regarding infrastructures and current conditions in the as well as industry expectations, some suggestions have been presented for interaction between government and Iran's civil aircraft industry.

The strategy of this study is to suggest appropriate policies to the Islamic Republic of Iran to deal with the country's aerospace industry. What is considered in this section is other countries' interaction with their own aerospace industries.

Therefore, the basic questions in this section are as follows:

1. Is civil aircraft industry of other countries considered as an independent industry or is considered as depended to government?

2. In other words, are civil aircraft markets adjusted by hidden agents or they are accompanied by governments' interventions?

3. In the case of governments' intervention in the industry, how would be the form and procedure of intervention?

The resources used in this study include documents, books, articles, technical reports and websites as well as interview with experts that each of these resources answered part of our questions regarding the mode of interaction between government and aircraft industry in different countries.

According to investigations, the best possible methods to manage this information are the following stages:

- Exact description of the problem

- Hypothesizing

- Data extraction and evaluating hypotheses

- Summary and presentation of results

\subsection{Hypothesizing}

Making appropriate hypotheses is an important part of the procedure, because its huge effect on the rest of the study. In this study, in order to make appropriate hypotheses, extensive studies were conducted on resources and various evidences regarding support or the lack of support from the government were extracted. After several sessions of discussion about results, these evidences were divided as five hypotheses in Table 1:

Table 1. Hypotheses related to government's support of aircraft industry

\begin{tabular}{|l|l|l|}
\hline & hypothesis & Descriptions \\
\hline 1 & $\begin{array}{l}\text { Spillover of military research } \\
\text { in the civilian sector }\end{array}$ & $\begin{array}{l}\text { Governments do not directly support the civil aircraft industries. } \\
\text { Instead, they support their own military industries and present the } \\
\text { results of military studies and this reduces the steady costs of civil } \\
\text { industry studies. }\end{array}$ \\
\hline 2 & $\begin{array}{l}\text { Supporting projects } \\
\text { (companies) through long-term } \\
\text { loans }\end{array}$ & $\begin{array}{l}\text { Due to long-last of aircraft industry, the governments deposit } \\
\text { financial resources to the industry and initiate its return after the } \\
\text { profitability of the plan. In fact, the governments provide the initial } \\
\text { capital, the capital cost and the working capital. }\end{array}$ \\
\hline 3 & $\begin{array}{l}\text { Globalization reduces supports } \\
\text { from aircraft industry }\end{array}$ & $\begin{array}{l}\text { Although governments are still interested in direct and indirect } \\
\text { supports of their aircraft industry, global pressures and enforcement } \\
\text { of global industry rules as a hinder of this request. Therefore, the } \\
\text { governments encounter limitations in supporting the industry. }\end{array}$ \\
\hline
\end{tabular}




\begin{tabular}{|l|l|l|}
\hline 4 & $\begin{array}{l}\text { Government's support in new } \\
\text { comer countries }\end{array}$ & $\begin{array}{l}\text { The aircraft industry in new comer countries (mainly eastern and } \\
\text { southeast Asian countries) is too young and needs more support. } \\
\text { Therefore, governments in these countries take more attention to this } \\
\text { industry. }\end{array}$ \\
\hline 5 & $\begin{array}{l}\text { Instead of government, the } \\
\text { companies take loan from other } \\
\text { financial institutes such as } \\
\text { banks or leasing institutes }\end{array}$ & $\begin{array}{l}\text { Due to the global industry pressure, governments cannot directly help } \\
\text { their industries and to circumvent these laws, they deposit money to } \\
\text { intermediary institutions for giving loan to the industry of interest. }\end{array}$ \\
\hline
\end{tabular}

\section{Data Extraction and Evaluating Hypotheses}

In this section, more than 1000 sheets related data are examined in more carefully and the approving or rejecting the hypotheses were obtained. These evidences state that the validity of hypotheses is subject to time and space. This means that each of the hypotheses are valid in certain times and countries and are not valid in other times or countries. Therefore, the scope of this study includes America, Europe, Russia, and Asia. Also, the study period includes the time period after 1990s.

\subsection{Analysis and Summarizing Data}

Analyzing and summarizing the obtained data regarding each specific location and time period, the type of government's interaction with the aircraft industry was clarified. The results indicate full support of all governments regarding aircraft industry, either direct or indirect. In the following, the procedure of the aircraft industry in different countries and after 1990s will be investigated.

\subsection{The Globalization Era: Defining the General Scope of Industry in These Years}

In this era, the rules of global trade spread its shadow over the civil aircraft industry. The GATT agreement which was formed after World War II and indicated its scope of presence during four decades was matured in this decade and the World Trade Organization (WTO) resulted. Due to the intense competition among American and European aircraft firms as well as the direct supportive subsides these industries were receiving from governments, some conflicts were found among these countries. Following these conflicts, WTO went into action in order to organize things and new provisions were added to the GATT agreement.

In 1992 and after a period of mutual threats, America and European Union discussed upon a mutual agreement that would cover huge airliners (up to 100 passenger). The provisions of this agreement were prepared following the failure of negotiations between Airbus and McDonnell Douglas. The agreement of 1992 temporarily solved some of the conflicting issues regarding supportive proceedings and defined the scope of others. Based on this agreement:

- Production subsides were banned

- The use of sale supports became limited to the huge airplanes of Organization for Economic Cooperation and Development

- Direct government support became limited to 33 percent of development costs

- Supports could only be allocated to the projects which were receivable by 17 years loan

- The first 25 percent (from 33 percent) of the development cost should be returned based on governmental loan rate

- The left 8 percent should be returned with 1 percent more than the government loan

- The indirect supports were limited to 4 percent of firm's annual trade sale or 3 percent annual trade sale of industry in each country

- In special condition wherein much of the survival of civil aircraft manufacturing as well as firm's financial efficiency were in danger, the annulment of this agreement was authorized. Some believe that the USA has benefited more than Europe from 1992 agreement. The USA, for the first time, accepted that their aerospace industry received indirect supports from the Department of Defense and NASA. The European Union banned the production subsides and adopted the formal limitations regarding returnable investment plans of projects. More importantly, this agreement avoided Airbus to receive more than 33 percent of irreversible costs as refundable investment, while in the past, the loans granted by some of these governments were 100 percent of these costs. In response, the USA implemented some limitations, often unmeasurable, on indirect financial supports. 


\subsection{The Main Actors of Civil Aircraft Industry in These Years}

In these years, in addition to the previous actors, the Asian countries gradually entered the field of civil aircraft. The fall of Soviet Union at the beginning of this period reduced their competitiveness and the Russian firms gradually lost their share from the market.

\subsubsection{The USA}

An unbiased evaluation of historical documents indicate that the USA has a temporary, unintentional and at the same time effective policy in commercial aircraft industry. In fact, the framework of USA's domestic policy has provided important support for civil aircraft industry. The support of government from USA's civil aircraft industry has taken various forms:

- Encouraging the preparation of aircrafts for military purposes

- Supporting research and defensive and civilian development in aerospace

- Loan guarantee

- The airline regulations that develop competition through providing new aircrafts (differentiation strategy) rather than cost (cost strategy)

\subsubsection{Europe}

Europeans in this period still continued their support of aircraft industry. These direct supports were incompatible with the agreement of WTO and in 2004 and during a meeting that has been released by WTO, the representative of the USA pointed to some Europe's violations in 1992 agreement. For example, in this period, the Europe as the initial project aids, supports those projects which are not economically possible. The point is that after the failure of this project, this cost is ignored.

Gifts and public services in order to improve, expand and develop the facilities if Airbus sites along with Airbus-380 production is another example of these supports that as a public investment on Airbus facilities have been evolved in Hamburg in Germany, Toulouse in France, Briton in England and several locations in Spain. In general, the Europeans in this period ignored the laws of world trade in order to strengthen the aircraft industry.

\subsubsection{Russia}

Although Russia saw intense financial problems after the fall of Soviet Union, the authorities of this country in this period seriously emphasized the continuation of their industrial activities in the field of aerospace. In fact, the aerospace industry is considered as one of the most important assets of Russia in new era and after the fall of Soviet Union by which it could maintain its power and global standing. Also, the Russian government was going to diagnose and restore the Russia airlines following the Russian defense industry restructuring program. After three major air crash in 2006, the Russian civil aircraft industry has underwent the scrutinizing observation of the Russian government. "The Grand Union of the Aircraft Industry" was created through the establishment of the Unified Aircraft Corporation (UAC) by the government. The Russian government expected the UAC to have more than 20 contracts until 2007 regarding the fields of helicopters, sport airplanes and motors with the value of more than 380 million dollars. Now, USC is negotiating with the European Aerospace Defense and Space Corporation (EADS) to bind long-term design contracts as well as cooperation in anti-Airbus examples. In 2006, Russia allocated 5 percent of EADS to itself. In these years, the Russian military industry has turned to civil activities among which it can be referred to the development of Super Jet-100 aircraft by Sukhoi. On the other hand, the Americans considered Russia as a context to expand their own air operations. Due to the availability of infrastructures and significant experience in Russia, Boeing expanded the long-term relationships with Russia and invested 1 billion dollars on these cooperation including the establishment of mutual design center with 1300 Russian engineers. It was predicted that by 2012, Russia sells 350 to 400 Russian civil aircraft with the value of 6 to 8 billion dollars in domestic markets. Also, in the context of foreign markets, countries such as China, India and newly independent states of Soviet Union that have experienced the related products, have the sale potential between 150 to 200 aircraft with the value of 3 to 4 billion dollars. Air transportations in these countries are faced by high growth rate and low purchasing power of airlines; as a result, their need to cheap and efficient aircrafts is clear. Here, the following conditions in Russian aircraft industry can attract customers from different countries, even all around the world:

- Reduction in based costs, using government subsides which were allocated to these industries in previous 
years;

- Improved operational characteristics compared to similar western aircrafts;

- Compliance with international flight safety conditions as well as the environmental laws;

- The availability of maintenance and repair center network for the active aircrafts of the Soviet Union;

3.3.4 Asia

The expanding air transportation market in the world and especially in Asia, has been an important incentive for countries to enter the civil aircraft industry. According to the predictions, in the coming years, the Asian airlines would be one of the most important customers of the aircraft industry. This has encouraged the Asian countries to invest on this industry in order to reduce their dependence on the west. Of course, these countries have found the way to enter the aircraft industry through the cooperation with the western industry and transportation of aircraft design and manufacturing. The dominant Asian countries investing on civil aircraft industry include China, India, Japan and South Korea.

\subsection{The Summary of Governments Financial Support Data in These Years}

In the years after 1990s, despite the limitations created by WTO, the governments still continued various supports of these industries. In this section, these supports and helps along with the incentives to support civil aircraft industry were described extensively. In the following, in order to facilitate the financial assistance of the governments (discovering), these data will be presented in Table 2.

Table 2. Investigating the amount of financial supports (discovering) of governments regarding the aircraft industry

\begin{tabular}{|c|c|c|c|}
\hline Country & $\begin{array}{l}\text { Government's financial support from the aircraft industry } \\
\text { (million dollars) }\end{array}$ & receiver & Time period \\
\hline USA & $\begin{array}{l}\text { In the years after } 1992 \text { agreement regarding decreasing } \\
\text { government's support of the aircraft industry, USA provided } \\
\text { Boeing company with } 24000 \text { million dollars from which, } 6000 \\
\text { million dollars allocated to B787 project. Also, in B777 } \\
\text { project, USA used } 500 \text { million dollars of Japanese } \\
\text { government's loan which was provided by the Japanese } \\
\text { companies. }\end{array}$ & $\begin{array}{l}\text { Boeing } \\
\text { company }\end{array}$ & 1996-2014 \\
\hline $\begin{array}{l}\text { European } \\
\text { Union }\end{array}$ & $\begin{array}{l}3000 \$ \\
\text { The financial supports of the European countries from their } \\
\text { own aircraft industry or their support of Airbus have not taken } \\
\text { into consideration in this rate. This rate, is the direct financial } \\
\text { support of the European Union for the aircraft industry in this } \\
\text { continent. }\end{array}$ & $\begin{array}{l}\text { The European } \\
\text { aircraft } \\
\text { industry } \\
\text { (mainly } \\
\text { Airbus) }\end{array}$ & $1990-2011$ \\
\hline England & $\begin{array}{l}800 \$ \\
\text { The shares of different sections from this financial support in } \\
\text { England are as follows: } \\
\text { Military aerospace }(91 \%) \text {; engineering studies }(5 \%) \text {; civil } \\
\text { aircraft }(4 \%) \text {. }\end{array}$ & $\begin{array}{l}\text { Research } \\
\text { centers } \\
\text { aircraft } \\
\text { industry }\end{array}$ & 2009 \\
\hline France & $\begin{array}{l}180 \$ \\
\text { In addition to this amount in this year, the aerospace industry } \\
\text { of France took } 1000 \text { million dollars low-interest loan from the } \\
\text { European Investment Bank. }\end{array}$ & $\begin{array}{l}\text { Research } \\
\text { centers of } \\
\text { aircraft } \\
\text { industry }\end{array}$ & 2011 \\
\hline Germany & $\begin{array}{l}180 \$ \\
\text { Regarding the political condition of Germany after World War } \\
\text { II, the investment of this country in the aircraft industry is } \\
\text { lower, compared to other European countries. } \\
1625 \$ \\
\text { This program was one of the main axis of aerospace studies in } \\
\text { Germany. }\end{array}$ & $\begin{array}{l}\text { Civil research } \\
\text { centers } \\
\text { Aircraft } \\
\text { Research } \\
\text { program } \\
\text { (ARP) }\end{array}$ & 2012 \\
\hline
\end{tabular}




\begin{tabular}{|c|c|c|c|}
\hline Belgium & $\begin{array}{l}190 \$ \\
\text { Various portions of the financial support in Belgium are as } \\
\text { follows: air engineering studies (16\%), Airbus project }(82 \%) \text {, } \\
\text { academic studies }(8 \%) \text {. }\end{array}$ & $\begin{array}{l}\text { Civil research } \\
\text { centers }\end{array}$ & 2014 \\
\hline Netherlands & $\begin{array}{l}31 \$ \\
\text { Direct support of aircraft studies by the Belgian government } \\
286 \$ \\
\text { Investments of Belgium transportation and economy in civil } \\
\text { aircraft industry. }\end{array}$ & $\begin{array}{l}\text { Civil research } \\
\text { centers }\end{array}$ & 2002-2013 \\
\hline Italy & $\begin{array}{l}487 \$ \\
\text { In } 2003 \text {, the executive section of CNR and Italy's national } \\
\text { aerospace research program provided } 127.1 \text { and } 247.6 \text { million } \\
\text { euro to support the aircraft industry ( } 374 \text { million euro, equal to } \\
487 \text { million dollars) . }\end{array}$ & $\begin{array}{l}\text { Civil research } \\
\text { centers }\end{array}$ & 2009 \\
\hline Spain & $\begin{array}{l}978 \$ \\
\text { In addition to } 978 \text { million dollars ( } 752 \text { million euro) indirect } \\
\text { held, the Spanish government has provided companies with } \\
\text { more than } 5500 \text { million dollars ( } 4200 \text { million euro) loan. }\end{array}$ & $\begin{array}{l}\text { Civil research } \\
\text { centers }\end{array}$ & 2012 \\
\hline Austria & $\begin{array}{l}60 \$ \\
\text { Based on the principles of European commission, there is no } \\
\text { direct financial support in Austrian government. But, the } \\
\text { companies allocate about } 60 \text { million dollars to the research } \\
\text { section from their own income. }\end{array}$ & $\begin{array}{l}\text { Civil research } \\
\text { centers }\end{array}$ & 2013 \\
\hline Sweden & $\begin{array}{l}244 \$ \\
\text { The amount of financial support by the Swedish government } \\
\text { has been estimated assuming the research coefficient of } 15,0 \\
\text { and this fact that the government provides half of the research } \\
\text { expenditures. }\end{array}$ & $\begin{array}{l}\text { Civil research } \\
\text { centers }\end{array}$ & 2015 \\
\hline Japan & $\begin{array}{l}69 \$ \\
\text { In the case of Japan, new data are not available. But, based on } \\
\text { the information provided by Boeing Company, the export } \\
\text { value of Japanese companies in } 2004 \text { was more than } 875 \\
\text { million dollars. } \\
206 \$ \\
\text { The share of various sections from this financial support is as } \\
\text { follows: cooperation in B777 research ( } 35 \%) \text {; engine research } \\
(20 \%) \text {; cooperation in manufacturing Supersonic aircrafts } \\
(45 \%) \\
1588 \$ \\
\text { The financial support by the government for Mitsubishi } \\
\text { regarding cooperation with Boeing in feasibility project of } \\
30 \text {-seat aircraft } \\
500 \$ \\
\text { For cooperation of Japanese companies in B787 project } \\
\text { For cooperation of Japanese companies in B777 project } \\
{[17-20] \text {. }}\end{array}$ & $\begin{array}{l}\text { Boeing } \\
\text { contractors }\end{array}$ & $\begin{array}{l}1996 \\
2004 \\
1990 s\end{array}$ \\
\hline
\end{tabular}


Based on data and findings which were extensively provided in the previous chapters, it can be concluded that the governments' financial support from the civil aircraft industry, during the entire life of this industry as well as all countries that have this industry, has always been existed. But, the intellectual origins of these supports and on the other hand, incentives and reasons of these supports are not the same in different governments. The reasons that different countries have moved toward the aircraft industry can be summarized as follows:

- Military needs and using aircraft as an effective instrument in the wars, whether in terms of attacking or information collecting purposes

- The economic resources in selling aircraft in two sections of commercial and military aircrafts

- Providing the needs of domestic transportation through domestic production

- Obtaining international prestige having air technology

- Creating brand technologies in air technology and their influence on other industrial sectors as well as country's technology development

In tables 3 and 4, the reasons of why countries support the aircraft industry have been summarized.

Table 3 . The reasons why countries are supporting the aircraft industry

\begin{tabular}{|l|l|}
\hline USA & $\begin{array}{l}\text { The military needs and using aircraft as an effective instrument in war, whether in terms of } \\
\text { attacking or information obtaining purposes } \\
\text { Economic interests in selling aircraft in two sections of commercial and military aircrafts } \\
\text { Obtaining international prestige having air technology } \\
\text { Creating brand technologies in air technology and their influence on other industrial sectors as well } \\
\text { as country's technology development }\end{array}$ \\
\hline Euro & $\begin{array}{l}\text { Fear of dependence on the U.S. industry } \\
\text { The economic interests of the air industry } \\
\text { Attempts to obtain credit }\end{array}$ \\
\hline Russia & $\begin{array}{l}\text { Providing the domestic needs } \\
\text { Manufacturing cheap and efficient aircraft for India and China as well as newly independent } \\
\text { countries }\end{array}$ \\
\hline Japan & $\begin{array}{l}\text { Independence in the civil aircraft industry and providing the domestic needs (maintaining the } \\
\text { international prestige) } \\
\text { Taking an important section of the civil aircraft market from the west and providing civil aircrafts } \\
\text { for the developing market of East Asia and then, for all countries } \\
\text { Learning the technology of aircraft design regarding designing military aircrafts }\end{array}$ \\
\hline China & $\begin{array}{l}\text { The rapid growth of air transportation in this country } \\
\text { Manufacturing military aircrafts }\end{array}$ \\
\hline
\end{tabular}

Table 4. How different countries support the aircraft industry

\begin{tabular}{|c|c|}
\hline USA & $\begin{array}{l}\text { Granting long-term loans to companies in bankruptcy situation by pre-ordering their products } \\
\text { Increasing the research and military budgets and assigning some sections to the civil aircraft } \\
\text { industry } \\
\text { Promoting competition by supporting bankrupting companies } \\
\text { Making intense connection between civil and military sections } \\
\text { Research supports of the aircraft industry through intermediaries (e.g. NASA) } \\
\text { Tax relief, supporting exportation, and developing the infrastructures needed by the aircraft } \\
\text { industry } \\
\text { Providing a part of aircraft project costs through making partnership with companies or countries } \\
\text { regarding the proiect (the U.S. companies somehow share the investment risk with other }\end{array}$ \\
\hline
\end{tabular}




\begin{tabular}{|c|c|}
\hline & countries) \\
\hline Europe & $\begin{array}{l}\text { Making infrastructures for the civil section to use scientific and research achievements resulting } \\
\text { from the military projects } \\
\text { Transferring the military projects to the civil aircraft industry } \\
\text { Direct support of the civil aircraft industry } \\
\text { Granting loans and guaranteeing them } \\
\text { Debt relief } \\
\text { Guarantee against exchange rate losses } \\
\text { Tax relief } \\
\text { Supporting exports through providing export credits } \\
\text { Supporting the developments of airlines (bringing prosperity to civil aircraft market) }\end{array}$ \\
\hline Russia & $\begin{array}{l}\text { Direct financial support } \\
\text { Repayment guarantee of the granted loans to the leasing companies by the government in special } \\
\text { cases } \\
\text { Subsides on interest rates in the loans that are allocated to the air industries by the banks } \\
\text { Government's partnership in the net investment of the selected leasing companies } \\
\text { Tax relief laws for aircraft leasing companies } \\
\text { Mixing civil aircraft manufacturers with military aircraft manufactures } \\
\text { Creating political context for air production exports } \\
\text { Developing airlines (bringing prosperity to civil aircraft market) } \\
\text { Providing financial counseling services for the aircraft industry (manufacturers and operators of } \\
\text { air transportation) } \\
\text { Tariffs to imports foreign aircrafts } \\
\text { Changing the existing laws to attract foreign investments in aircraft industry }\end{array}$ \\
\hline Japan & $\begin{array}{l}\text { Creating monetary fund for the development of Japanese aircraft industry } \\
\text { Granting loans to active companies in the aircraft industry (Japan's loan granting model is unique. } \\
\text { The Japanese companies are exempted from the repayment of } 30 \% \text { of government loans and it is } \\
\text { interesting to note that the rest } 70 \% \text { will not be returned as cash; rather, this rate will be invested } \\
\text { in new projects. In fact, the government loan is considered as an initial capital for companies } \\
\text { which will be allocated against implementing projects and new plans). } \\
\text { Creating legal infrastructures } \\
\text { Supporting the aircraft industry in the form of insurance law (the Japanese government } \\
\text { encourages banks to grant loan to airlines in order to purchase domestic aircrafts. The government } \\
\text { ensures the repayments of these loans). }\end{array}$ \\
\hline China & $\begin{array}{l}\text { Foreign investments in attracting capital from other countries } \\
\text { Direct financial support from the domestic production }\end{array}$ \\
\hline
\end{tabular}

\subsection{A Brief Comparison of the Situation in Iran with Other Countries Regarding the Aircraft Industry}

The aerospace industry is accompanied by high technology and having access to it, demands high rates of investment and time. Based on the field studies, although the Iranian air industry managers are eager to develop the aircraft industry and independence in this field, do not appropriately understand the place of this industry in financial and industrial planning. According to the published information, the Iranian government has allocated 200 million dollars to produce Endogenous civil aircraftcivil aircraft that this rate has been provided in long-term period (about 12 years).

In order to clarify the investment size of different countries, we should take a look at Table (5) wherein a summary of investments and governments' supports of the aircraft industry has been provided. According to this 
table, between 1992 and 2006, the USA has granted more than 24 billion dollars to the Boeing Company (annual average of about 1700 million dollars). Until 2015, this rate is estimated as 43000 billion dollars. However, the USA in an agreement with Europe in 1992, made a commitment to decrease its financial supports to the aircraft industry. Another interesting point is that from more than 24000 million dollars financial supports in these years for Boeing, about 2100 million dollars have been from the subsides that the Japanese government has allocated to its partnership with the U.S. Aircraft Industry. In other words, when the U.S. government had to limit its financial supports regarding the aircraft industry, compensated this rate through attracting foreign partners as well as using that country's subsides. This is not in conflict with world trade laws and from this point of view, no problem has been created for the U.S. government.

Table 5. The comparison of governments' annual financial supports from the civil aircraft industry (these information have been extracted form Table 2)

\begin{tabular}{llll}
\hline Country & $\begin{array}{l}\text { The revealed financial } \\
\text { supports (million dollars) }\end{array}$ & $\begin{array}{l}\text { The time period of } \\
\text { financial support }\end{array}$ & $\begin{array}{l}\text { The average annual financial } \\
\text { support (million dollars) }\end{array}$ \\
\hline USA & 23.675 & 15 years $(1992-2014)$ & 1.600 \\
England & 800 & 1 year $(2013)$ & 800 \\
France & 2.548 & 1 year $(2002)$ & 2.548 \\
Germany & 180 & 1 year $(2003)$ & 315 \\
& 1.625 & 12 years $(1995-2006)$ & \\
Belgium & 190 & 1 year $(2003)$ & 190 \\
Netherlands & 31 & 6 years $(1998-2003)$ & 53 \\
& 286 & 6 years $(2002-2007)$ & \\
Italy & 487 & 1 year $(2003)$ & 487 \\
Spain & 978 & 1 year $(2002)$ & 987 \\
Sweden & 244 & 1 year $(2004)$ & 244 \\
Japan & 69 & 1 year $(1995)$ & 484 \\
& 206 & 1 year $(20012)$ & \\
& 1.588 & 10 years $(1990 \mathrm{~s})$ & \\
Iran & 500 & 10 years (1990) & \\
\hline
\end{tabular}

USA, particularly in recent decades, has supported its civil aircraft industry, mostly with indirect methods (i.e. transferring the military projects to Boeing, research investment in institutes such as NASA, etc.). Therefore, the amounts mentioned in the table, are the minimum support that the U.S. government has provided for Boeing.

In Europe, also, countries such as England, France, Germany, and Italy have allocated the highest incomes to themselves, respectively. But, the highest government supports in Europe are related to France with 2500 million dollars per year. Regarding the Japanese government's support of the aircraft industry, no new statistics is available. However, as can be seen from the Table (2), Japan is interested in cooperation with Boeing industries in new projects and significant investments have been allocated to this issue (more than 100 million dollars in 15 years $=140$ million dollars per year). Examining the government support sizes of the aircraft industry in different countries and comparing them with the government supports in Iran indicates that Iran is far from other countries regarding the investments in the aircraft industry. However, the total annual budget allocated to civil aircraft industry in Iran, is equal to only $8 \%$ of the annual supports of French government from the aircraft industry, $12 \%$ of the U.S. annual support from Boeing and about $4 \%$ annual supports of the Italian Government regarding this industry.

\subsection{Supportive Patterns and Policies in Aircraft Industry in Iran}

Through studying the history of the civil aircraft industry and the way through which governments have interacted with this industry, various patterns have been extracted. These patterns have been examined and reviewed in a brainstorming session; accordingly, government's supportive patterns have been extracted from Iran's aircraft industry.

\subsubsection{Classifying Supportive Policies}

Classifying supportive policies are important, since they provide an overview for the supportive policies. Also, due to the harmony with the literature on industrial policy as well as easier transfer of data to the experts of this 
field, this work is necessary. To classify supportive policies, first, three classifications are presented:

Classification 1:

In this classification, the policies are classified into four groups:

$>$ Direct financial supports

> Granting special privileges to domestic aircrafts (to strengthen and stimulate the market)

$>$ Policymaking

$>$ Building infrastructures

Classification 2:

In this classification, the policies are classified into two groups:

$>$ Direct financial supports

$>$ Indirect financial supports

Classification 3:

In this classification, the policies are classified into four groups:

$>$ Policies focusing on funding

$>$ Policies focusing on human resource supply

$>$ Policies focusing on scientific and research infrastructure supply

$>$ Policies focusing on market supply (demand)

After intensive investigations and implementing each of these classifications in practice, finally, some revisions were performed regarding the classifications and the supportive policies were divided into three following groups:

$>$ Funding support policies

$>$ Market strengthening support policies (assigning privileges to domestic aircrafts)

$>$ Infrastructure building support policies, including:

$>$ Legal infrastructure

$>$ Physical infrastructure

$>$ Research infrastructure

$>$ Institutional infrastructure

$>$ Political infrastructure

$>$ Cultural infrastructure

In solutions that are considered in the category of financial supports, the government somehow helps the development of aircraft industry by direct financial supports. This financial support can be as allocating special budgets, directly for aircraft industry or by granting long-terms loans with low-interest rates.

In strengthening the market and assignment of privileges, the government gives concessions to the buyers of endogenous civil aircrafts. These concessions would make the domestic aircraft markets more prosperous and warmer; therefore, indirectly help the profitability of domestic aircraft industry. Some cases will be located in infrastructure group, each need to create contexts by the government and as the result; the aircraft industry will be strengthened. These infrastructures have been classified into six groups:

Legal Infrastructures: With adopting appropriate laws, the government should create the context for effective activity of the aircraft industry. For example, through adopting laws, the government can create an atmosphere wherein the need to aircraft increases that can bring consequences such as attracting the capital of the private section. Also, the adaptation of these laws lets this industry to decrease its costs or through activities in contexts other than aircraft, provide its funds.

Physical Infrastructure: The aircraft industry development needs special physical infrastructure that by creating them, the government can provide better condition for this industry in country's economy circle. 
Research Infrastructures: In these infrastructures that have been created with the goal of knowledge development, especially aerospace knowledge, the government creates a research-scientific area with its own cost that pays attention to the production of necessary aerospace industry knowledge.

Institutional Infrastructures: Some of aircraft industry problems are related to the lack of necessary institutes in the circle of this industry. In order to make efficient function of this industry, the government should create such institutes.

Political Infrastructures: In some of the cases, the government should prepare the context for exporting the aircraft industry products as well as competition with foreign productions or strengthening the possibility of mutual cooperation between domestic industries and foreign industries and these will be possible through the development of relations between government and other countries.

Cultural Infrastructures: In these cases, through culture-building practice among people, the government can provide the context to enter domestic aircraft industry products among people or encourages the culture of using aircraft. Table 6 shows these supportive patterns and policies (without prioritizing and classification) have been introduced.

Table 6. Supportive patterns and policies for Iran's civil aircraft industry

\begin{tabular}{|c|c|c|}
\hline $\begin{array}{l}\text { Political } \\
\text { category }\end{array}$ & \multicolumn{2}{|c|}{ Recommended policies for the development of Iranian Aircraft Industry } \\
\hline $\begin{array}{l}\text { Financial } \\
\text { supports }\end{array}$ & \multicolumn{2}{|c|}{$\begin{array}{l}\text { Allocating budget until the project is fully operational } \\
\text { Allocating long-term loans ( } 10 \text { years) with repayment } \\
\text { Allocating loan for exportation } \\
\text { Allocating budget to Iran's military versions }\end{array}$} \\
\hline $\begin{array}{l}\text { Strengthening } \\
\text { market }\end{array}$ & \multicolumn{2}{|c|}{$\begin{array}{l}\text { Granting loans to airlines for purchasing Endogenous civil aircraft } \\
\text { Granting double subsides for the fuel of Endogenous civil aircraft } \\
\text { Granting operating license to foreign LCCs for buying Endogenous civil aircraft } \\
\text { Granting transportation license to Endogenous civil aircraft with low custom fee in the lines } \\
\text { with few passengers } \\
\text { Bearing the costs of repair and maintenance of Endogenous civil aircraft by the government } \\
\text { Granting loans for new airlines (particularly for flights to Iraq) regarding buying } \\
\text { Endogenous civil aircraft } \\
\text { Granting subsides to the government employees in the case of using Endogenous civil } \\
\text { aircraft } \\
\text { Granting double subsides to Endogenous civil aircraft fuel for transportation }\end{array}$} \\
\hline & Legal & $\begin{array}{l}\text { Banning the use of jets in the routs less than } 1000 \mathrm{~km} \\
\text { Law to transfer at least } 20 \% \text { of the financial volume of military air projects } \\
\text { from the armed forces to Iran Aircraft Manufacturing (IAM) } \\
\text { Issuing license for industrial projects in IAM } \\
\text { Granting license to IAM to downsizing the manufacturing sector } \\
\text { (transferring manufacturing facilities to private companies) } \\
\text { Forcing the military sections to buy Endogenous civil aircraft in the case of } \\
\text { need for fleet renewal } \\
\text { Transportation } \\
\text { Forcing the use of Endogenous civil aircraft for medical section in the case of } \\
\text { need for patients transportation } \\
\text { Forcing to buy Endogenous civil aircraft for all ministries } \\
\text { Facilitating license granting to aircraft clubs (at least } 30 \text { clubs in various parts } \\
\text { during first three years) } \\
\text { Granting license to IAM for exporting civil aircraft parts } \\
\text { Granting license to IAM regarding the supplement of bonds in quick impact } \\
\text { projects } \\
\text { Increasing customs tariff for buying Turboprop Aircraft }\end{array}$ \\
\hline & Physical & $\begin{array}{l}\text { Creation of air transportation industry poles in Isfahan (establishment of } \\
\text { research centers, technology parks as well as urban infrastructure for experts) }\end{array}$ \\
\hline & Research & Government's financial support of basic and applied researches related to the \\
\hline
\end{tabular}




\begin{tabular}{|l|l|l|}
\hline & & aircraft industry for IAM's research projects \\
\hline & Institutional & $\begin{array}{l}\text { Creating an intermediary institute in the private section (SBU \& SME) for } \\
\text { outsourcing projects with information classification of military industries }\end{array}$ \\
\hline Political & $\begin{array}{l}\text { Developing foreign relationships for strengthening international industrial } \\
\text { cooperation } \\
\text { The presence of IAM's representatives in industrial negotiations between } \\
\text { Iran and other countries regarding components exportation, assembly, } \\
\text { collaborative production design and marketing }\end{array}$ \\
\hline Cultural & $\begin{array}{l}\text { Culture building regarding the use of Turboprop Aircraft (e.g. movie, story, } \\
\text { competitions, etc.) } \\
\text { Expanding the culture of aircraft sport (as an instrument of GA markets to } \\
\text { develop the potential market for IAM) }\end{array}$ \\
\hline
\end{tabular}

In fact, the supportive policies regarding the aircraft industry are not of the same priority to be implemented in Iran. This means that some of these policies are suitable regarding the country's condition, direct and indirect effects, the productive time, the required capital for implementation and so on. Therefore, their implementation in Iran would lead to significant and tangible results. While some of these policies are less relevant to the country's condition, their implementation, at least in short-term and mid-term periods, would not bring significant results. Therefore, the issue of policies prioritization issue happens. But before prioritizing the policies, the evaluation criterion and the related weights should be clarified. In this chapter, first, policies' evaluation criterion have been introduced and next, using analytic hierarchy process (AHP) method, the related weights will be determined.

To evaluate government's supportive policies, it is possible to use the following criterions (Table7):

Table7. Main criterions for government's supportive policies

\begin{tabular}{ll}
\hline C1 & To be proportionate with the political infrastructure \\
\hline C2 & To be proportionate with the commercial infrastructure \\
C3 & To be proportionate with the industrial infrastructure \\
C4 & To be proportionate with the cultural infrastructure \\
C5 & reating jobs \\
C6 & Return time (early return) \\
C7 & Helping military capabilities and increasing security \\
C8 & Increasing welfare and aircraft industry \\
C9 & Scientific and industrial growth \\
C10 & The resulting economic benefits compared to investments \\
\hline
\end{tabular}

\subsection{Prioritizing Evaluation Criterion}

In AHPmethod, first, the evaluation criterion is compared. These comparisons compared with the situation wherein all criterion are compared, provide more exact comparison. Based on this method, the priority of each criterion will be determined according to the following pattern(Table 8):

Table 8. Priority scale of criterions

\begin{tabular}{llllll}
\hline Priority & Preferred Equally & Preferred moderately & $\begin{array}{l}\text { Preferred } \\
\text { strongly }\end{array}$ & Very strongly preferred & Extremely preferred \\
\hline Credit & 1 & 3 & 5 & 7 & 9 \\
\hline
\end{tabular}

For example, if the $\boldsymbol{i}$ th criterion has high priority over $\boldsymbol{j}$ th criterion, the priority credit of $\boldsymbol{i}$ is 7 times larger than $j$ and 7.1 times larger than i. In fact, the priority of each criterion regarding itself equals to 1 . After determining the priority values of various criterion, the square matrix is constituted according to the problem's criterion (here, 11 $\times 11$ matrix) that the priority credit of the criterion is registered in it. The specific vector of this matrix indicates 
the importance coefficient of various criterion that are used for estimating the final credit of each proposed policy. Table 9 shows rating the evaluation criterion of policies. Regarding the problem of interest, the comparison matrix of the criterion is created based on the comments of experts:

Table 9. Rating the evaluation criterion of policies in AHP method

\begin{tabular}{|c|c|c|c|c|c|c|c|c|c|c|c|}
\hline & $\begin{array}{l}\text { To be } \\
\text { proportionate } \\
\text { with the } \\
\text { physical } \\
\text { structure }\end{array}$ & $\begin{array}{l}\text { To be } \\
\text { proportionste } \\
\text { with the } \\
\text { industrial } \\
\text { infrastructure }\end{array}$ & $\begin{array}{l}\text { To be } \\
\text { proportionate } \\
\text { with the } \\
\text { political } \\
\text { infrastructure }\end{array}$ & $\begin{array}{l}\text { To be } \\
\text { proportionste } \\
\text { with the } \\
\text { commercial } \\
\text { infeture }\end{array}$ & $\begin{array}{l}\text { To be } \\
\text { propertionate } \\
\text { with the } \\
\text { cultural } \\
\text { infrastructure }\end{array}$ & $\begin{array}{l}\text { Increasing } \\
\text { welfare } \\
\text { and } \\
\text { aircraft } \\
\text { industry }\end{array}$ & $\begin{array}{l}\text { Creating } \\
\text { jobs }\end{array}$ & security & $\begin{array}{l}\text { Scientific } \\
\text { and } \\
\text { industrial } \\
\text { growth }\end{array}$ & $\begin{array}{l}\text { The resulting } \\
\text { economic } \\
\text { benefits } \\
\text { compared to } \\
\text { investments }\end{array}$ & $\begin{array}{l}\text { Retum } \\
\text { time }\end{array}$ \\
\hline $\begin{array}{l}\text { To be } \\
\text { proportionate } \\
\text { with the } \\
\text { physical } \\
\text { structure }\end{array}$ & 1.0 & 3.0 & 4.0 & 5.0 & 7.0 & 0.3 & 0.2 & 3.0 & 0.3 & 0.1 & 0.3 \\
\hline $\begin{array}{l}\text { To be } \\
\text { proportionate } \\
\text { with the } \\
\text { industrial } \\
\text { infrastructure }\end{array}$ & 0.3 & 1.0 & 3.0 & 4.0 & 7.0 & 0.3 & 0.2 & 1.0 & 0.3 & 0.1 & 0.2 \\
\hline $\begin{array}{l}\text { To be } \\
\text { proportionste } \\
\text { with the } \\
\text { political } \\
\text { infrastructure }\end{array}$ & 0.3 & 0.3 & 1.0 & 3.0 & 5.0 & 0.3 & 0.1 & 0.5 & 0.3 & 0.1 & 0.2 \\
\hline $\begin{array}{l}\text { To be } \\
\text { proportionate } \\
\text { with the } \\
\text { commercial } \\
\text { infrastructure }\end{array}$ & .02 & 0.3 & 0.3 & 1.0 & 4.0 & 0.2 & 0.1 & 0.3 & 0.2 & 0.1 & 0.2 \\
\hline $\begin{array}{l}\text { To be } \\
\text { proportionste } \\
\text { with the } \\
\text { cultural } \\
\text { infrastructure }\end{array}$ & 0.1 & 0.1 & 0.2 & 0.3 & 1.0 & 0.1 & 0.1 & 0.2 & 0.1 & 0.1 & 0.1 \\
\hline $\begin{array}{l}\text { Increasing } \\
\text { welfare and } \\
\text { aircraft } \\
\text { industry }\end{array}$ & 3.0 & 3.0 & 4.0 & 5.0 & 8.0 & 1.0 & 0.3 & 3.0 & 1.0 & 0.2 & 0.5 \\
\hline Creatingjobs & 5.0 & 6.0 & 7.0 & 7.0 & 9.0 & 3.0 & 1.0 & 5.0 & 3.0 & 0.3 & 3.0 \\
\hline security & 0.3 & 1.0 & 2.0 & 3.0 & 5.0 & 0.3 & 0.2 & 1.0 & 0.3 & 0.1 & 0.2 \\
\hline $\begin{array}{l}\text { Scientific } \\
\text { and } \\
\text { industrial } \\
\text { growth }\end{array}$ & 3.0 & 3.0 & 4.0 & 5.0 & 7.0 & 1.0 & 0.3 & 3.0 & 1.0 & 0.2 & 0.3 \\
\hline $\begin{array}{l}\text { The resulting } \\
\text { economic } \\
\text { benefits } \\
\text { compared to } \\
\text { investments }\end{array}$ & 7.0 & 7.0 & 7.0 & 8.0 & 9.0 & 5.0 & 3.0 & 7.0 & 5.0 & 1.0 & 4.0 \\
\hline Return time & 4.0 & 5.0 & 5.0 & 6.0 & 9.0 & 2.0 & 0.3 & 5.0 & 3.0 & 0.3 & 1.0 \\
\hline
\end{tabular}

Finally, priority and the weight coefficient of evaluation criterion of policies shown in following tables(table 10 and 11).

Table10.The weight coefficient of evaluation criterion of policies

\begin{tabular}{ll}
\hline $\mathrm{C} 1$ & 0.15 \\
\hline $\mathrm{C} 2$ & 0.09 \\
$\mathrm{C} 3$ & 0.07 \\
$\mathrm{C} 4$ & 0.05 \\
$\mathrm{C} 5$ & 0.03 \\
$\mathrm{C} 6$ & 0.22 \\
\hline
\end{tabular}




\begin{tabular}{ll}
\hline C7 & 0.47 \\
C8 & 0.08 \\
C9 & 0.20 \\
C10 & 0.75 \\
\hline
\end{tabular}

Table11. Priority and the weight coefficient of evaluation criterion of policies

\begin{tabular}{ll}
\hline C10 & 0.75 \\
\hline C7 & 0.47 \\
C6 & 0.22 \\
C9 & 0.20 \\
C1 & 0.15 \\
C2 & 0.09 \\
C8 & 0.08 \\
C3 & 0.07 \\
C4 & 0.05 \\
C5 & 0.03 \\
\hline
\end{tabular}

To determine priority of proposed support policies, scoring tables given to the experts. Experts at first separately were filled the tables, then in a meeting, in cases where there is much controversy, debate and exchange of views took place. In the following, necessary criteria were considered for the evaluation of these policies and the main criteria were introduced in this area. The relative priority of criteria (weight of each criterion) were determined using the method of AHP and expert's opinion and finally scoring proposed policies on the main criteria, priority of these policies was given. Finally, support policies in three packages of infrastructure, strengthen financial markets and were classified.

\subsubsection{Infrastructure Policies}

This policy has earned the highest rating of supportive policies and therefore, according to experts, with regard to the main criteria has the highest executive priorities. The formation of new lending for the purchase of domestic aircraft and the development of foreign relations for strength international industrial cooperation are most important priorities of this support package. The government-sponsored basic has to continue to applied research related to the aviation industry to carry out research projects.

It also creates an institutional interface between military industry and the private sector for outsourcing projects that classified necessary information till more capacities should be used to the civilian sector. On the other hand it is very expensive to design and build aircraft, authorization to the aircraft firms to enter the quick ancillary businesses such as tooling, and the order of the other related industries have been proposed.

Technology transfer contracts and representatives of aviation companies in the industrial negotiations between Iran and other countries discuss for export segment, assembly, collaborative product design, marketing and management added value in such partnerships contracts are issued confirmed by experts. Also increase customs tariffs to buy external regional aircraft, forced to buy indigenous aircraft to other parts of the state and military if necessary transport fleet renewal are made with such policies set forth in the package.

\subsubsection{Policies Strengthen Market and Complementary Activities}

Policy of this package is average rating will reached by primary criteria and therefore their proportion to conditions in the country and their effectiveness at total average evaluated. This policy can be diagnosed as a case study with experts beside the infrastructure policies applied. Most important recommendations policies in this section include forced to use indigenous aircraft for needed therapy sectors for air transport of patients and bear the costs of its maintenance by the government and planning for military versions of indigenous aircraft.

It also promotes and culture for the use of indigenous aircraft and expand the culture of sport aviation (develop GA market as one of the potential markets for civil aircraft industry) through the media and accelerating the transfer of licenses to aviation clubs will lead to a boom in the industry.

In order to compete use market as well as industrial products gradually granting operational licenses to foreign LCC against buying indigenous aircraft on the government's agenda. Transfer loans to export air products and legislation to a significant share of military air project from armed forces to Aircraft Company are other elements of the package policy. 


\subsubsection{Financial Policy}

These policies of this package have earned a low rating according to main criteria and therefore they fit with the overall conditions in the country and their effectiveness evaluated weak. Therefore, these policies are not proposed for steady state and can only in the case and limited time to solve problems applied. For example, the budget allocation to the project portfolio is fully operational; granting additional subsidies to fuel consumption of indigenous aircraft prohibit the use of jets on short-range routes are such as these policies. As well as granting permission to carry goods with low customs in lines with low passenger are rare and the supply of bonds in quick impact projects, granting discount to government employees for use in civil aircraft, can be considered as a case.

\section{Conclusion}

Evaluation of policy package the essential point is obtained that public policies of propulsion are of infrastructure kind that requires less state spending. Financial policy of this package consists of only two cases reversible granting loans to airlines and financial support of basic and applied research in the civil aircraft industry. According to the researchers, this part of the project is the results were very reasonable and highly compatible with experiences of successful countries. In addition to the results the government's role focuses as a contributor and facilitator of industrial development and implied that the government should not be involved in this industry shall be inquisitive. Supplement policies mostly fall into two categories: policies to boost the market and policies to create conditions for ancillary activities. Implementation of these policies also needs to spend money from the government and the software methods are applicable, as well as emphasized the role of government policy.

In the package of accessories policies flavor of financial assistance and spending government cost seen. As also noted above these policies can in case and with a time limit up to a certain ceiling (up to industry to minimize financial independence) applied. The government should see these packages and investment policies for temporary look. In total, according to the experiences of other countries in the development of the civil aircraft industry, the researchers of this study suggest the following path to the development of the civil aircraft industry in Iran.

Financial and institutional policies to strengthen the industry in the early years and offset the high initial investments implemented. These policies should be timed and with quantitative targets applied.

Use of complementary policies (strengthen the market and doing side activity) in parallel to the mid-term financial policy and adopting infrastructure from now until the distant future, so that in the long run these policies are only used in industry and other policies gradually to reach zero.

Suggested this route to protect the civil aircraft industry on the basis of these facts have been formed that the role of government in steady state have to change to supporting and facilitating and the role of ownership and control in reduced. This is consistent with the spirit of the Constitution of the Islamic Republic of Iran on the one hand and the general policies of the system and on the other hand with global trends governing the interaction between government and compatibility industry.

Accordingly, infrastructure policy must be implemented in the long run. Survey of the history of the civil aircraft industry in different countries reflects the reality that the industry cannot develop without government assistance. The administrators of the industry in our country believe that the government cut funding in the current situation could lead to stagnation and bankruptcy industry, therefore, early implementation of infrastructure policies and cut funding, will help the development of this industry.

Given these two important facts internal and external pressures continue to prevent direct government financial assistance in the not too distant future, to the civil aircraft industry and financial assistance will continue and, leading to reduced incentives for progress and competition in the industry; the government shall grant financial assistance, determine timetable. On the one hand this table should not be long (because will not have impact on stimulate industry) and also because the industry cannot be too short of time to adapt to changing conditions and removal of financial assistance.

Based on available evidence, the demand for civil aircraft in the country is much higher than domestic production capacity. The strengthening of the market in the early years are not suitable policies and apply them only when the industry's ability to reach acceptable production (in terms of quantity) will be relevant.

Due to the growth of civil aircraft projects, it is predicted Iran Aircraft Industries in the medium term to this situation (in term of production) achieved the other hand, with respect to the control role of state should be reduced gradually, it has proposed that these policies are weak again after several years of implementation and 
strengthening of market infrastructure development policies implemented only in the long run.

\section{References}

Amsden, A. H. (1986). Asia's Next Giant, South Korea and Late Industrialization. Oxford University Press.

Bhushan, N., \& Kanwal, R. (January 2004). Strategic Decision Making: Applying the Analytic Hierarchy Process. London: Springer-Verlag. ISBN 1-85233-756-7

David, P., \& Alan, M. P. (2004). Industrial Subsidies and the Politics of World Trade: The Case of the Boeing 7e7"; David Pritchard; Canada-United States Trade Center, Department of Geography, State University of New York, Buffalo, NY 14261. The Industrial Geographer, 1(2), 57-73.

David, P., \& Alan, M. P. (2008). Strategic Destruction of the North American and European Commercial Aircraft Industry: Implications of the System Integration Business Model. Canada-United States Trade Center, Department of Geography, University at Buffalo, The State University of New York, Buffalo, NY 14261; Retrieved from http://www.custac.buffalo.edu/

David, P., \& Alan, M. P. (2008). The emergence of Japan as a subsidized competitor in the commercial aircraft sector: The New Trade War. By David Pritchard and Alan MacPherson; Canada-United States Trade Center, Department of Geography, University at Buffalo, The State University of New York, Buffalo, NY, 14261; Retrieved from http://www.custac.buffalo.edu/

EU (2007). The WTO Boeing-Airbus dispute: Details of the US subsidies to Boeing challenged by the EU. European comission. Brussels. Retrieved from http://ec.europa.eu

Hans, J. W., Aaron, J. G., \& George, W. H. (2005). Study of european government support to civil aeronautics R\&D. TECOP International, Inc., 7916 Laurelridge Road, San Diego, CA 92120.

Labor, R. J. (2007). Boeing's Diffusion of Commercial Aircraft Technology to Japan: Surrendering the U. S. Industry for Foreign Financial Support. http://dx.doi.org/10. 1007/s12122-007-9005-2

Niosi. J. (2012). A report on R\&D Support for the Aerospace Industry, A Study of Eight countries and One Region.

Pavcnik, N. (2002). Trade disputes in the commercial aircraft industry. World Economy, 25, 733-751

United States Measures Affecting Trade in Large Civil Aircraft (2007). (Second Complaint)- (DS353). Executive summary of the first written submission of the united states.

Vesta, J. (1995). Industrial Policy and Japaneses Economic Development. Claredon Press, Oxford.

Wang, J. E., \& Feng, J. J. (2007). China's Air Passenger Transport: An Analysis of Recent Trends. Eurasian Geography and Economics, 48(4), 469-480.

World Bank (1992). World Development Report, Knowledge for Development, Oxford University Press.

World Trade Organization; WT/DS316/1, G/L/697, G/SCM/D62/1 (2004). European communities and certain member states-measures affecting trade in large civil aircraft.

\section{Copyrights}

Copyright for this article is retained by the author(s), with first publication rights granted to the journal.

This is an open-access article distributed under the terms and conditions of the Creative Commons Attribution license (http://creativecommons.org/licenses/by/3.0/). 